\title{
Chapter 2 \\ Life Expectancy Is Taking Center Place in Modern National Pension Schemes - A New Challenge for the Art of Projecting Mortality
}

\author{
Edward Palmer
}

\subsection{Introduction}

Mortality scenarios are a standard tool in projecting costs of defined benefits (DB) pay-as-you-go pension systems. Government actuaries and statisticians have used mortality projections to estimate the costs of national pay-as-you go defined benefit pension systems since their conception, although the development of computer technology in the 1970s and 1980s was a prerequisite for more sophisticated analysis. With the maturation of computer technology, the possibilities to model and examine various assumptions are nowadays more-or-less unbounded. We have become used to official publications from, for example, the Office of the Government Actuary in the US or, in Sweden, the National Social Insurance Board, that provide a picture of future contributions and payments given various demographic and economic scenarios. These reports provide a picture of the financial development of national pension systems.

Financial projections illuminating the financial status of pension systems are indisputably important, not the least because pay-as-you-go systems transfer considerable resources from workers to pensioners. As life expectancy increases, and assuming current retirement patterns, $25-30 \%$ of the total population in the OECD will be pensioners within the coming three decades. There is now considerable debate in countries all around the world about how to cope with the aging population. The World Bank's publication Averting the Old Age Crisis (1994) constituted a milestone in the debate. The World Bank recommended that its client countries adopt multi-pillar schemes, with a funded "second pillar" playing an important role.

\footnotetext{
E. Palmer $(\bowtie)$

Social Insurance Economics, Uppsala University, Uppsala, Sweden

Research Division, Swedish National Social Insurance Board, Stockholm, Sweden e-mail: edward.e.palmer@gmail.com
} 
The Swedish pension reform, first published as a proposal in Swedish in 1992, and then legislated by parliament as a framework law in early 1994, introduced the notional defined contribution scheme to the international political arena. Since the mid-1990s, there has been a large-scale conversion of national pension schemes from defined benefit (DB) to defined contribution (DC) - both notional defined contribution (NDC) and financial defined contribution (FDC). As countries convert to DC schemes, life expectancy projections are used to calculate individual pensions in national systems.

The purpose of this paper is to summarize the dramatic change that has occurred in the design of national pension schemes in the past 10 years and to discuss the need for accurate mortality projections in this context.

\subsection{Basic Pension Economics - The Role of Mortality}

The financial costs of a pay-as-you-go pension system are determined by a few key parameters. In the aggregate these are the size of an average benefit relative to the average wage, the number of workers and the number of pensioners. The ratio of the latter two is the system dependency ratio. The system dependency ratio can also be computed as the number of years people work related to the number of years they are retired with a benefit. These are two sides of the same coin. The policy parameters of a country are the size of a pension and the level of the contribution rate. The demographic and economic determinants of pensions are largely exogenous to policy, although these can respond to system design.

These ideas follow from the two fundamental equations of pension economics, which provide the point of departure for an overview of the links between mortality and pay-as-you-go pension systems. Where bars denote averages, and $\mathrm{p}$ and $\mathrm{w}$ depict pensions and wages, these equations are:

$$
\text { Contribution rate }=\frac{\bar{p}}{w} * \frac{\text { pensioners }}{\text { contributors }}
$$

or for the average participant in the scheme (see e.g. Palmer 1999)

$$
\text { Contribution rate }=\frac{\bar{p}}{w} * \frac{\text { years in retirement }}{\text { years of work }} \text {. }
$$

The first equation tells us that pension costs, measured in terms of the contribution rate on wages, is determined by the average benefit times the number of recipients, and the contribution base, expressed in the first equation as the product of the average wage and the number of contributors. If pension payments grow faster than contributions, the contribution rate needed to finance them increases, and vice versa. The second equation expresses the same relationship for the average scheme participant in terms of years worked and years of retirement. It tells us that more years of retirement in relation to years of work will result in higher pension costs.

Mortality affects both the numerator and the denominator of the first equation. Declining mortality among working age persons increases the size of the working 
age population and the (potential) labor force. Decreasing mortality of persons above the pension age increases the population of retirees. In other words, the age distribution of mortality improvements matters.

In terms of the second equation, increasing mortality from the age of retirement implies that people will have to work more years - at the same wage - to receive a benefit of a given level and with a fixed contribution rate. Conversely, if the pay-asyou-go system is designed so that a benefit is defined, for example, in terms of the number of covered years of work and contributions required to qualify for a benefit of a fixed amount, then declining mortality, i.e. more years in retirement, increases the contribution rate that the younger generation of workers has to pay in order to sustain the fixed level benefit over more years.

This is a static picture, however. Assume now that the labor force grows at the rate $\lambda$ and productivity at the rate $g$, and that the average wage grows at the rate of growth of productivity. Then the first equation tells us a number of things. First, if benefits are inflation-indexed, which is a common form of indexation for pay-asyou-go systems, then positive values of productivity and labor force growth will counteract negative effects on costs of increasing longevity after retirement. During the past two decades some countries have taken advantage of this mechanism to reduce costs, by replacing wage indexation of benefits with price indexation. ${ }^{1}$

The first equation also tells us that a country can afford wage indexation as long as the labor force grows faster than the number of pensioners. With wage indexation, the real-valued (inflation adjusted) pension grows with the rate of increase in productivity, and productivity growth is shared between workers and pensioners. ${ }^{2}$ Many countries have seen this as a desirable redistributional aspect of a pay-as-yougo pension system. Whether or not this level of ambition can be attained depends on the connection between the construction of the pension system and the demography behind changes in the work force and the number of pensioners.

Assume now net migration of zero and a birth rate that reproduces the population. Maintaining a fixed ratio between the average pension and the average wage through wage indexation of benefits over time requires that the positive effect on the work force of declining mortality surpass the increase in pension payments resulting from decreased mortality among the retired population.

Of course, the effect on the working population of decreasing mortality will have to be associated with sufficiently healthy years of life to make a difference.

\footnotetext{
${ }^{1}$ The UK did this in the early 1980s. This has also been one of the mechanisms used by transition country governments during the 1990s to cut back on burdensome pension costs - where the immediate problem was a dependency ratio around 1.5 workers per pensioner, due to very generous pension ages inherited from the old communist regimes.

${ }^{2}$ Denoting the rate of inflation by $\mathrm{p}$, the nominal wage rate grows at $(1+\mathrm{p})(1+\mathrm{g})$, as does the nominal wage base. For a fixed ratio of pensioners to contributors (the first equation) it is possible to index benefits with this factor, and maintain a constant contribution rate, since the numerator increases at the same rate as the denominator.
} 
In addition, the economy must be able to employ the extra labor created in this way. ${ }^{3}$ Employability is usually viewed as a short-run problem, however, as the growth of the working age population and labor supply are usually regarded as the long-run determinants of a country's economic growth, together with the rate of growth of productivity.

The second equation provides technical insight into how a pay-as-you-go system can be designed to adjust to changes in the life expectancy of pensioners. Given that people continue to work with the average wage, increasing life expectancy after retirement can be dealt with by increasing the minimum benefit age at the rate of change in the life expectancy of retirees. This also requires that people work and contribute during the additional time prior to a retirement $\operatorname{age}^{4}$ that is sufficient to maintain a fixed ratio of years of retirement to years of work. Alternatively, the pay-as-you-go scheme can be constructed as a notional defined contribution scheme as discussed below.

\subsection{NDC and FDC Schemes - And Life Expectancy}

A notional defined contribution - NDC - scheme is the pay-as-you-go equivalent of the financial defined contribution - FDC - scheme. The difference is in the rate of return, which in the NDC scheme is based on economic growth, whereas it is a financial rate of return in the FDC scheme. In the neo-classical Golden Rule, these are equivalent in the long run. However, many current writers make the claim that FDC schemes should always be expected to yield a higher return (e.g., Feldstein and Samwick 1997, 1998). This claim is based on the observation that the financial rate of return has surpassed the rate of economic growth over the past half century in the US. Data for Sweden (e.g., Frennberg and Hansson 1992) yield a similar result, at least up to the fall of the stock market in 2001-2002.

How does an NDC scheme work in practice? In the NDC public scheme, just as in any public or privately managed FDC scheme, wage earners pay contributions based on a fixed contribution rate. The value of these are accredited their accounts - this is the defined-contribution feature of the system. Contributions are paid on earnings as long as people work, and if people combine work with a pension then they continue to pay contributions on earned income and increase their pension capital accordingly. The previous year's account value is indexed annually with a nominal per

\footnotetext{
${ }^{3}$ In addition, the years added to the older population need to be (relatively) healthy years in order not to create other social costs, for example, increasing costs for health and home care of the elderly. In a broader model of the social "costs" of caring for the elderly, e.g., health and home care, could be added to the numerator of the first equation by adding the cost per capita.

${ }^{4}$ In a DB scheme where the right to a full benefit is based on a certain number of years, e.g., 40, it might be necessary to increase this number to assure that the period of working and contributing also become longer as the minimum pension age is increased.
} 
capita wage index in Sweden, ${ }^{5}$ where the system was conceived in 1992-1994. The wage sum is used for indexation in Latvia and GDP in Italy, both of which were legislated in 1995.

The NDC annuity is calculated by dividing the value on the account at the chosen age of retirement with a factor based on unisex life expectancy at the age of retirement. In addition to this, in Sweden a real rate of return of $1.6 \%$ and in Italy $1.5 \%$ is calculated into the annuity. This form of front-loading is an alternative to possible wage indexation (from a lower initial level) over the lifetime. Annuities are also indexed to annual changes in prices in both countries. Annual indexation in the Swedish scheme also includes an adjustment for digressions of actual real growth from $1.6 \%$, and if estimated system liabilities exceed assets a balancing adjustment to bring the system back into financial equilibrium. This keeps the aggregate contribution rate in line with the individual contribution rate of $16 \% .^{6}$

Gora and Palmer (2002) have recently made the claim that the main difference between NDC and FDC is in the nature of the "fund," which in the NDC case can be seen as a fund of bonds bearing the rate of return of the wage sum (tax base) in the economy, where it is a needless exercise to sell the bonds on the market fund, since this simply creates transaction costs. These authors also note that both NDC and FDC funds are illiquid until retirement, and that from retirement both are paid out as yearly annuities. Both FDC and NDC have the advantage that they eliminate negative externalities by creating a direct link between contributions and benefits. On the other hand, an FDC scheme is associated with the positive externality of creating financial funds. If these are placed in non-government debt instruments they contribute to financing private investment and - if they do not offset private saving provide additional financing for economic growth. The major difference between NDC and FDC is, thus, that NDC does not create this opportunity. On the other hand, an FDC scheme that invests solely in government bonds can be viewed as a cost-inefficient NDC scheme, since the transaction costs of marketing the debt do not create offsetting revenues.

Proponents of NDC claim that it represents a paradigm shift in social security thinking (e.g., Palmer 2000). By creating a direct link between contributions and the annuity and by basing the size of the annuity on life expectancy at retirement, NDC

\footnotetext{
${ }^{5}$ In principle, a system must follow the development of contributions, i.e. the wage sum on which contributions are based, in order to maintain financial equilibrium. This means that if the per capita wage is used to index notional capital and benefits, then the system must be equipped with a brake that keeps it in financial equilibrium when labor force growth $(\lambda)$ is negative. In the Swedish system a financial balance is kept that relates estimated system assets to liabilities. Ceteris paribus, if liabilities exceed assets because labor force growth is negative, both benefits and notional capital will be indexed downwards to bring the system back into equilibrium (See Palmer 2000, 2002; Settergren 2001).

${ }^{6}$ In principle, the Italian system should achieve a long-term equilibrium around the weighted contribution rates of the employed and self-employed if contributions and accrual factors are brought more in line. In practice, the absence of a mechanism to offset chronic divergence from the imputed return of $1.5 \%$ may lead to financial difficulties. Palmer (1999) examines the stability conditions of the NDC PAYGO system, as does Valdés-Prieto (2001).
} 
systems reduce the impact on system costs of individual behavioral choice and of unexpected changes in longevity. In comparison, in the DB framework the burden of the risk is unclear. It may fall on future generations of workers or on present workers before they retire.

NDC pension schemes are subject to the same "political risks" as DB pay-as-yougo - "political" management of public funds causing low rates of return, special interest lobbying, etc. For example, in Italy, the rate credited into the notional account is actually higher than the payroll tax earmarked for pensions, while in Poland it is lower, which is synonomous to taxing accounts. The NDC provides a framework for monitoring the costs of these interventions, as Fox and Palmer (1999) have argued in discussing the Latvian NDC scheme.

An NDC scheme with demographic reserves and indexation of notional capital and benefits that follows the growth of the contribution base, and with an annuity based on life expectancy projections that on average do not deviate from the outcome for birth cohorts, yields approximate long-run financial stability (Palmer 1999). If as in Sweden indexation follows the per capita wage rate and life expectancy is based on current outcomes - rather than a cohort projection - then there is a built in risk that the assets of the system will fall below the liabilities. Financial balance is secured in Sweden through a balance mechanism, based on current estimates of system assets and liabilities.

Briefly, the Swedish balance mechanism works as follows. If assets, measured as the estimated future stream of revenues from contributions and the current value of the system's buffer fund(s), are less than liabilities, i.e., claims on future payments of pensions of pensioners and the notional account values of workers, the balance index falls below unity. In this case, both notional account values and benefits are adjusted to bring the system back into balance.

The Swedish NDC scheme was started with a large buffer fund inherited from the old system - these funds will help to cover the demographic pressure associated with the large birth cohorts of the 1940s. Various scenarios using relatively extreme demographic and economic assumptions show that it is likely that if the balance index has to be used in the future, the negative effect on future benefits during the whole retirement period of a pensioner is not likely to be more than 10 per cent in total, given some of the worse scenarios (Settergren et al. 2000).

Most importantly for the present topic, both FDC and NDC schemes work more efficiently with good expectancy projections. Poor projections give rise to a need for adjustment, and in general, do not provide the information needed by scheme participants to plan their "economic lives" given information about the development of their own cohort's life expectancy and the expected value of their own stream of pension benefits. 


\subsection{It's More Important Than Ever to Project Life Expectancy Accurately}

Public NDC and FDC schemes have been introduced in a number of countries since the mid-1990s. ${ }^{7}$ In addition, also since 1995, public FDC schemes have been introduced in a large number of Latin American countries, and have become popular in especially the transition countries of Central and Eastern Europe. ${ }^{8}$ These countries join, then, some of the forerunners of funded schemes, among them, Chile, Australia, Denmark, the Netherlands, Switzerland and the UK. The newer countries in the league differ from many of the forerunners, however, in their explicit DC construction. For example, the mandated employer schemes in Australia and the "opting out" schemes in the UK have been largely financial defined benefit (FDB) schemes, although there is a recent tendency for these also to convert to FDC. The difference between an FDB and an FDC scheme is small, however, since financial solidarity requires that life expectancy projections be on target in both.

In principle, there are two approaches that can be applied in estimating the life expectancy factor to be used in the calculation of annuities for NDC, and FDC, schemes. One is to base the projection on the current period tables - perhaps with some form of smoothed moving average. This is the approach applied by Sweden. ${ }^{9}$ The major alternative is to produce a cohort projection.

This is the approach applied by Latvia. The Swedish projection is revised yearly with new information on mortality, as is the Latvian projection.

The revision process differs in Latvia, however. Latvia bases changes in the projection of life expectancy on a professional judgment, ${ }^{10}$ with a demographic analysis as the point of departure. In the revision process, it is asked whether new information provides sufficient evidence to revise the existing long-term projection. ${ }^{11}$ One could view this approach as a sort of error-correction mechanism. In principle, the methods available for projecting life expectancy for FDC schemes

\footnotetext{
${ }^{7}$ In addition to Sweden, Italy, Latvia and Poland, which have already been mentioned, versions of NDC schemes have been introduced in Kyrgyzstan, and in Russia.

${ }^{8}$ See Fox and Palmer (2001) for a discussion of the driving forces behind this movement.

${ }^{9}$ Although the life expectancy factor is continuously updated in Sweden, since people continue to live longer after receiving their pension, the procedure used to calculate it will underestimate the actual outcome. This is counterbalanced either through other, positive factors contributing to the financial balance, or through triggering the balance index (see above).

${ }^{10}$ The judgment is the product of a white paper written by a leading demographer and a discussion in an official committee of demographers and actuaries set up for this purpose. This is discussed in Krumins et al. (2001).

${ }^{11}$ The procedure was initiated in 1999, and in the first 3 years thereafter, no revision of the long-term projection had been made.
} 
are exactly those available for NDC. In the FDC context an effort is made to project a life expectancy factor that is expected to give long-run system solvency. ${ }^{12}$

In sum, as countries convert to DC schemes, life expectancy projections are used to calculate individual pensions in national systems. The question is whether the state of the art in projecting mortality can meet new demand created by large public schemes that are turning towards annuities based on life expectancy.

\subsection{Final Comments}

With conversion to public NDC and FDC schemes in Sweden, ${ }^{13}$ as well as elsewhere, individuals have been given greater responsibility to plan their own working careers and saving with respect to a desired level of resources during retirement. In the DC framework resources during retirement are linked to contributions during the whole working career, and the level of a benefit is also determined by life expectancy at the age chosen for retirement. In this framework, knowledge about the development of cohort life expectancy becomes an important informational input into the economic plans of individuals.

One of the goals of policy makers is to loosen up the idea of "a" pension age at which everyone is expected to exit the labor force, that is the concept of the "statutory" or "mandatory" pension age that implanted itself so deeply in the minds of employees, unions and employers since the 1960s. The focus is to shift from the "right" to leave the labor force at age, for example 60, with a defined lifelong benefit, to the "right" to work as an older worker - but in a work environment that is friendly to older workers.

The transition from national DB to DC schemes presupposes a future where people can freely choose between work and retirement - combining a partial or full benefit with partial or full retirement. It also presupposes that individuals invest enough in their human capital (personal health, education and training) to be able to remain in the labor force longer. Today the de facto age of exit from the labor force for men and women together is below 60 in the OECD countries. There is evidence that this has been influenced by national benefit schemes (Gruber and Wise 1999).

\footnotetext{
${ }^{12}$ In FDC schemes there is a trade off between the rate of return and life expectancy in the sense that inaccuracies in the projection of the life expectancy factor can be counterbalanced by a better rate of financial return on funded capital. In the Swedish NDC construction, since positive labor force gains are undistributed, i.e. indexation is with $(1+\mathrm{g})(1+\mathrm{p})$, these together with good returns on the buffer fund(s) can counterbalance the clear inaccuracy in the projection of life expectancy at retirement resulting from not attempting to account for some additional increase in life expectancy of cohorts after retirement.

${ }^{13}$ Note that Sweden, as other countries that have introduced NDC and FDC schemes, has a minimum guarantee, which has not been discussed in the present context.
} 
Countries are now aiming to raise this age. National DC (NDC or FDC) schemes are a tool that can help promote this goal, and this is an important reason why countries are introducing them. ${ }^{14}$

To conclude, in order to plan for retirement in a DC environment, individuals need good information about their cohort's life expectancy. Work career and saving plans will then be formulated in accordance with this information, thereby determining lifetime resources and their distribution over the life cycle.

\section{References}

Feldstein, M., \& Samwick, A. (1997). The economics of prefunding social security and medical care benefits (NBER Working Paper, No. 6055). Cambridge, MA: NBER.

Feldstein, M., \& Samwick, A. (1998). Two percent personal retirement accounts: Their potential effects on social security taxes and national saving (NBER Working Paper No. 6540). Cambridge, MA: NBER.

Fox, L., \& Palmer, E. (1999). Latvian pension reform (Social Protection Discussion Paper No. 9922). Washington, DC: The World Bank.

Fox, L., \& Palmer, E. (2001). New approaches to multi-pillar pension systems: What in the world is going on? In J. Stiglitz et al. (Eds.), New ideas about old age security. Chicago: World Bank/ University of Chicago Press.

Frennberg, P., \& Hansson, B. (1992). Swedish stocks, bonds, bills and inflation. Applied Financial Economics, 2, 79.

Góra, M., \& Palmer, E. (2002). Shifting perspectives in pensions (Working Paper). Warsaw: Center for Economic and Social Research (CASE).

Gruber, J., \& Wise, D. A. (1999). Social security programs and retirement around the world. Chicago: University of Chicago Press.

Krumins, J., Palmer, E., Svenssson, I., \& Vanovska, I. (2001, June 7-9). Life expectancy trends and calculations of projected life expectancy at retirement - From transition to post-transition - The case of Latvia. Paper presented at the European Population Conference, Helsinki, Finland.

Palmer, E. (1999). Individual decisions and aggregate stability in the NDC system. Mimeograph.

Palmer, E. (2000). The Swedish pension reform: Framework and issue (World Bank Pension Primer). Washington, DC: The World Bank.

Palmer, E. (2002). Swedish pension reform - How did it evolve and what does it mean for the future? In M. Feldstein \& H. Siebert (Eds.), Coping with the pension crisis: Where does Europe stand? Chicago: University of Chicago Press.

Settergren, O. (2001). The automatic balance mechanism of the Swedish pension system - A non-technical introduction. Wirtschaftspolitische Blätter, 4, 339.

Settergren, O., Holmgren, N., Leander, J., \& Mikula, B. (2000). The automatic balance mechanism in the Swedish pension system (RFV Analyserar 2000:1). Stockholm: The National Social Insurance Board.

\footnotetext{
${ }^{14}$ Another is that the value of pension rights equals the account value at any given time. This makes it easy to move between jobs, occupations and countries without losing rights, eliminates the potential locking in effect of some formulations of DB schemes, for example, DB final-salary schemes.
} 
Valdés-Prieto, S. (2001). The financial stability of notional account pensions. Scandinavian Journal of Economics, 102(3), 395-417.

World Bank. (1994). Averting the old age crisis: Policies to protect the old and promote growth. Washington, DC: World Bank.

Open Access This chapter is licensed under the terms of the Creative Commons Attribution 4.0 International License (http://creativecommons.org/licenses/by/4.0/), which permits use, sharing, adaptation, distribution and reproduction in any medium or format, as long as you give appropriate credit to the original author(s) and the source, provide a link to the Creative Commons license and indicate if changes were made.

The images or other third party material in this chapter are included in the chapter's Creative Commons license, unless indicated otherwise in a credit line to the material. If material is not included in the chapter's Creative Commons license and your intended use is not permitted by statutory regulation or exceeds the permitted use, you will need to obtain permission directly from the copyright holder. 